\author{
Кравець М. С., \\ кандидат фбілософбських наук, \\ доцент каферри соціології та культурологї \\ Національного лісотехнічного університету Украӥни
}

\title{
ФІЛОСОФІЯ СТАЛОГО РОЗВИТКУ ІНФОРМАЦІЙНОГО СУСПІЛЬСТВА
}

\begin{abstract}
Анотація. У статті обгрунтовано припущення, що практичні результати реалізації стратегії сталого розвитку, як у Свропросторі, так і на українських теренах, не є однозначними. Вони часто мають пропагандистський характер, а саму стратегію варто характеризувати як стратегію добрих намірів. Зазначено, що в Україні «використання терміна «сталий розвиток» набуло модного характеру без всестороннього його обгрунтування. Він присутній у назвах більше половини науково-практичних конференцій із проблем усієї палітри життя суспільства. Не нехтують
\end{abstract} цим терміном і політичні лідери, які у своїх виступах використовують його без адекватного розуміння проблем, що ним окреслюються» [1, с. 158]. Про перехід людства на шлях «сталого», або всебічно збалансованого, розвитку було заявлено на початку останнього десятиліття XX століття. Підсумкові документи «сталого розвитку», що були ухвалені на саміті «Планета Земля» у 1992 році, стосувалися насамперед проблем збереження навколишнього середовища й особливостей розвитку соціальних спільнот щодо загроз своєму існуванню в перспективі. У такому розумінні «сталий розвиток» виступав частиною буття, невід'ємним складником розвитку соціумів. Однак розвиток світових спільнот у XX столітті більше нагадував їхній «сталий розвиток», ніж він виявився у першій чверті XXI століття. Інформаційне суспільство здеформувало віками оптимізовані співвідношення між потребою «мати» і життєвим «бути». Адже «коли ми хочемо взнати, що складає умови людського існування, то виникають головні питання: у чому полягає сутність людини? що робить людину людиною?» [2, с. 22]. Реалізація стратегії сталого розвитку протягом майже тридцяти років показала, що в самих принципах сталого розвитку не були враховані можливі прогностичні наслідки глибинних перетворень постіндустріального суспільства. Формування інформаційного формату соціумів змінило всю палітру проблем у системі «людина - природа - людина», які до цього вирішувались еволюційним шляхом розвитку. Раніше вони мали локальний, а не загальноглобалізаційний характер.

На наш погляд, за останні тридцять років так і не вдалося досягти всесвітнього консенсусу в реалізації стратегії сталого розвитку. Насамперед низка соціумів прийняли принципи сталого розвитку стосовно своїх регіональних умов без їх економічного забезпечення. Міжнародні форуми на найвищому рівні у 2018-2020 роках продемонстрували заклики і наміри до співпраці. Сталий розвиток виявився ефективним лише у сталому зростанні нових, більш загрозливих, викликів, що починають турбувати людство.

Ключові слова: інформаційний простір, сталий розвиток, структура, засади сталого розвитку, система, аналіз, синтез, раціональність, оптимізація, процес, інтерпретація, принципи.
Актуальність дослідження зумовлена фактором часу, причинами ухвалення стратегії сталого розвитку, досягнутими результатами iii реалізації на європейських і українських теренах, потребами аналізу зміни змісту складників сталого розвитку в умовах нових системних викликів інформаційного суспільства. Насамперед «як поняття «сталий розвиток» складається із двох термінів, які суперечать один одному. У термінологічних словниках <..> визначений зміст цих понять. Розвиток - це процес із зміною якості. Він не може існувати, оскільки термін «сталий» його блокує < .. >, розвиток культури у форматі «сталого розвитку»» [3, с. 176]. Тому не в усіх випадках він $€$ коректним, особливо щодо розвитку окремих її складників. Зокрема, професор В. Бондаренко вважає термін «сталий розвиток» невдалим, пропонує замінити його іншим - «збалансований розвиток» [4, с. 355-356].

На наш погляд, українські дослідники не звернули увагу на три події, що презентували початок 90-х рор. По-перше, Комісія Європейського Союзу подає розгорнуте визначення інформаційного суспільства, яке набуває статусу загальновизнаної соціально-філософської та політичної категорії. По-друге, у науковий обіг уводиться поняття «сталий розвиток». По-третє, виходить фундаментальна праця Альберта Гора «Земля у рівновазі. Екологія і людський дух». Це свідчить про те, що політична еліта сучасних демократій усвідомила наслідки людської діяльності, побачила реальні загрози своєму існуванню. «Саміт Землі» означав історичний поворотний пункт у тривалій боротьбі за підвищення міжнародного усвідомлення правди про кризу глобального довкілля. Він зумів спрямувати світ до кращого розуміння того, як і чому майбутній економічний прогрес тісно пов'язаний із надійною політикою, що сприяє захисту довкілля і мудрому управлінню природними ресурсами» $[5$, с. 1$]$.

Аналіз змісту принципів сталого розвитку свідчить про те, що вони були сформульовані на рівні мислення тогочасної політичної еліти про розвиток суспільства, його співвідношення із природою. У змісті документів соціально-політичних інститутів тогочасної євроспільноти переважають тенденції раціональності. На початку 90-х рр. ХХ ст. стало зрозумілим, що технологія розв'язання нових проблем потребує i нових методологічних підходів. Політичний істеблішмент розвинутих демократій почав мислити категоріями проєктів, програм, прогнозів. «На час, коли було висунуто ідею сталого розвитку, суспільство добре усвідомлювало вже цінність не тільки природничо-наукового або технічного знання, але також і соціально-гуманітарного. Навіть більше, достатньою мірою було оцінено вже й інформаційно-евристичне значення <...> [6, с. 47]. 
Однак цього виявилось недостатньо. Необхідні були знання вхідних та вихідних координат явища та «володіння методикою переходу від перших до других» [7, с. 92] у короткій та довгостроковій перспективі. Вхідні координати явища були відомі. Це насамперед зростання кількості природних катаклізмів, безповоротна втрата багатьох видів рослин і тварин, поява нових хвороб, катастрофічне забруднення водного і повітряного басейнів, бідність, масові збройні конфлікти, тероризм тощо. Із класичного погляду вихідні параметри формувались на основі вхідних. Під них необхідно було розробити відповідні програми дій. Що стосується методики переходу від одних координат до інших у такому класичному розумінні проблеми, то західноєвропейська наукова думка напрацювала на той час певний комплекс відповідних алгоритмів. Практично за такою схемою була сформована стратегія сталого розвитку. Ця соціальна технологія була адекватною тогочасному розумінню сутнісних складників у розвитку соціальних спільнот. Вона була логічним продовженням ідей раціоналізму та функціональності оточення людини, притаманним Європі епохи класицизму.

Зазначимо, що «філософія переходу до сталого розвитку у європросторі 90-х рр. супроводжувалась постійним зростанням всіх соціально-економічних показників соціумів. Тільки за досягнення певного рівня соціальних благ був запропонований перехід до сталого розвитку» [1, с. 160]. Логічно припустити, що перехід до сталого розвитку економічно відсталих соціумів (а таким $€$ і український соціум) законсервує їхній розвиток, перетворить їх на придаток природних ресурсів і малокваліфікованої робочої сили. Наукові відкриття та технічні винаходи будуть оперативно вивозитись у високорозвинуті соціуми, а національна еліта буде на дотації небагатьох країн для підтримання рабського статусу свого населення. Частково цей процес уже започаткований на українських теренах. Українці поступово позбавляються своїх законно-етнічних прав на землю, корисні копалини, національні реліквії тощо. Відбувається процес вимивання родових засад українства, засадами загальних (не властивих українцям) цінностей, що ні чим не відрізняється від попередньої ідеї єдиного радянського народу, випробуваної на українських землях. Тому висловимо дискусійну ідею про те, що для України стратегія сталого розвитку у прийнятому нашим політичним керівництвом виді $€$ шкідливою для національної розбудови власної держави.

Як відомо, стратегія сталого розвитку містить 16 цілей сталого розвитку на період 2016-2030рp. Із них у трьох ключовим $\epsilon$ термін «раціонально». У «Філософському енциклопедичному словнику» даний термін розкривається як «розумне, доступне» тощо. На побутовому рівні використовується в контексті раціонального природокористування, характерного для інтенсивного господарювання. 3 позицій системного аналізу це означає «висмоктати» із системи все можливе без розширення об'єму системи. Отже, первісний зміст поняття виявився цілковито знівельованим у сучасному його розумінні та зведений до сприйняття як технології безвідходного виробництва. Як приклад, реалізація цілі за номером 15 (раціональне лісокористування) на українських теренах. Ліс у Карпатах на величезних площах вирізаний «раціонально». Нічого не залишилось, вивезені навіть пеньки з коренями. Як зазначає Держлісагентство України, обсяги незаконних вирубок у 2019 р. сягнули рекодного значення. Отже, стратегія сталого розвитку вимагає суттєвої корекції, насамперед у контексті свого понятійного апарату.
У третьому тисячолітті науковці не звернули уваги на те, що у природі, крім принципів раціональності, $є$ інший принцип - оптимальності перебігу процесів. I якщо би ціль 15 була окреслена як оптимальне використання, то 3 неї випливала 6 низка нових похідних принципів щодо збереження лісового масиву. А державні інститути під час ухвалення рішень змушені були б керуватися іншими методиками аналізу і синтезу складних соціально-політичних проблем.

На наш погляд, у процесі реалізації концепції сталого розвитку в останньому десятиріччі почали проявлятися два паралельні взаємно заперечуючі процеси. 3 одного боку, сталий розвиток вимагає об'єднання зусиль усього світового співтовариства, 3 іншого - «глобальна соціальна нерівність, розшарування за ознаками якості життя, статусу і можливостей самореалізації у глобальному суспільстві за умов глобальної інформаційної відкритості та втрати безпосереднього взаємозв'язку між бідністю та багатством продукують атмосферу соціального невдоволення і напруження, котрі проявляються як у постіндустріальному центрі (терористичні акти в економічно багатих і розвинутих країнах - M. K.), так і на перифеpiї світової системи (Близький Схід тощо - М. К.)» [8, с. 268]. Отже, малодослідженою і невирішеною виявляється проблема інформаційного повсякдення, адекватного стратегії сталого розвитку. «Що може бути «найпрозорішим» та «найзрозумілішим» за повсякдення? Коли говоримо про нього, то на перший погляд все «само сробою зрозуміло»: повсякдення $є$ повсякденням. Світ, у якому живе людина, - це ії повсякденний світ. Розуміння життя розпочинається 3 повсякденного життя < ...> [9, с. 5]. Суттево зазначити, що з погляду західної гуманітаристики повсякдення - «певна основа всього життя людини» $[9$, c. 7]. Однак інформаційне повсякдення розуміння і сприйняття конкретної проблеми - це складна і натепер малодосліджена сукупність зовнішніх і внутрішніх векторів факторної інтерпретації нашої поведінки. Чому в поведінці великих соціальних утворень у деякі періоди часу відсутня логіка? Чому сьогодні у великих соціальних спільнот за явного розуміння негативних впливів інформаційного суспільства, пов'язаних із самознищенням, відсутні логіка і потреба в реалізації стратегії сталого розвитку? А цілком зрозумілі для всіх соціумів положення невідкладних завдань залишаються поза їхньою увагою.

Реалізація стратегії сталого розвитку на українських теренах поки що має радше декларативний, ніж конкретно виважений (політично й економічно), усебічно обгрунтований і зрозумілий характер. Водночас українські вчені досить добре розробили коло проблем сталого розвитку як у межах сьогодення, так і на перспективу. На нові явища в розвитку соціальних спільнот звернена увага в монографіях і багатьох публікаціях. «Сьогодні вже неможливо говорити про сталий розвиток, - зазначають О. Білорус і Ю. Мацейко, - безвідносно до проблем глобалізації, розвитку постіндустріального інформаційного суспільства, оновлення нової (інтелектуальної) економіки. Різні виміри стійкості і сталості розвитку, такі, як економічний, соціальний, екологічний, у своій єдності набувають нового характеру в умовах інформаційного суспільства $<\ldots>$ » $[10$, с. 18]. Отже, у таких умовах має насамперед змінюватися методологія (технологія) розв'язання проблем. Аналізуючи тактичні документи, що ухвалюються в полі дії стратегії сталого розвитку, як уважають державні структури, можна зробити висновок, що до інноваційних форм управління 
сталим розвитком українському управлінському апараду досить далеко. Зазвичай рішення ухвалюються по факту виконання завдань. В умовах інформаційного суспільства рішення варто формувати за фактом сукупної дії, факторної інтерпретації соціальних явищ.

Аксіологія проблеми реалізації стратегії сталого розвитку на українських теренах, на наш погляд, є найбільш складною частиною явища. Буденні цінності мільйонів українців (як вижити) не адекватні цілям сталого розвитку, а буденні цілі українського політичного істеблішменту (як більше отримати) суперечать духовним історичним засадам української людності. Водночас реалізація цілей сталого розвитку можлива лише за однієї умови, коли означені цілі оволодіють духовним світом кожного українця. Український політикум протягом останніх 25 років не зміг виробити зрозумілої для населення стратегії розвитку держави в координатах сталого розвитку. За соціологічними дослідженнями, проведеними автором, менше одного відсотка 3 опитаних могли сказати щось про дану стратегію. Для широкого загалу вона є невідомою. Такою вона буде залишатись доти, поки на ії реалізацію не будуть спрямовані не стільки економічні, скільки духовно-інтелектуальні ресурси політичного простору держави. Як відомо, 30 вересня 2019 р. Президент України Володимир Зеленський підписав указ про цілі сталого розвитку України до 2030 р. 15 вересня 2017 р. Уряд України презентував національну доповідь «Цілі сталого розвитку України». У часовому проміжку протягом майже трьох років змінювалися лише уряди, міністри, директори корпорацій, президенти i більше нічого. Варто зауважити, що означені українські реалії суттєво впливають на авторитет держави й опосередковано гальмують інвестиції в українську економіку.

Можна зробити висновок, що поки що філософія української влади в системі координат сталого розвитку інформаційного суспільства $є$ досить посередньою і незрозумілою для широкого загалу як українського, так і міжнародного соціуму.

\section{Jimepamypa:}

1. Кравец Н. Стратегия устойчивого развития информационного общества: философия безопасности. The survival strategy in terms of bioethics, philosophy and medicine : Collection of scientific articles with international participation. Vol. 4 (20). Chisinau, 2014. P. 158-162.

2. Фромм Э. Анатомия человеческой деструктивности. Пер. с англ. Э. Телятникова, Т. Панфилова. Минск : ООО «Попурри», 1999. $624 \mathrm{c}$.

3. Кравець М. Культурологія: розвиток культури в інформаційному вимірі : підручник для студентів вищих навчальних закладів I-IV рівнів акредитації, природничих та технічних спеціальностей. Дисципліна за вибором. Львів : Новий Світ-2000, 2019. 260 с.

4. Бондаренко В. «Сталий розвиток»-не найточніший термін. Вісник державного університету «Львівська політехніка». № 336. Проблеми української термінології : матеріали 5-ї Міжнародної наукової конференції. Львів : Львівська політехніка, 1998. С. 353-358.

5. Гор А. Земля у рівновазі. Екологія і людський дух. Переклад 3 англ. : ВГО «Україна. Порядок денний на XXI століття»; І Інститут сталого розвитку. Київ : Інтелсфера, 2001. 404 с.

6. Семенюк Е. Філософські засади сталого розвитку. Львів : Афіша, 2002. $200 \mathrm{c}$
7. Kravec Mykola Zagadnienia analizy metodologicznej kultury politycznej. Demokracja konflikt wykluczenie. Instytut filozofii uniwersytetu wroclawskiego. Wroclaw, 2008. S. 91-98.

8. Суліма Є. Глобальний соціальний порядок постіндустріалізму : монографія. 2-е вид., доповн. Київ : Генеза, 2004. 336 с.

9. Карівець I. Повсякдення: між трансценденталізмом і дивовижністю : монографія. Львів : Видавництво Львіської політехніки, 2012. $256 \mathrm{c}$.

10. Білорус О., Мацейко Ю. Глобальна перспектива і сталий розвиток : системні маркетологічні дослідження. Київ : МАУП, 2005. 492 с.

Kravets M. The philosophy of sustainable development of the information society

Summary. The article describes the assumption that the practical results of implementing a sustainable development strategy both in Eurospace and Ukrainian territories are not straightforward. They often have a propaganda nature, and the strategy itself should be described as a strategy of good intentions. It is noted that in Ukraine using the term "sustainable development" became fashionable without its comprehensive justification. This term is present in the names of more than half of the scientific and practical conferences on the problems of the whole palette of society life. It is also used by political leaders who use it in their speeches but do not understand what problems described by it [1, p.158]. In the early 90's of the twentieth century was declared the transition of humanity to "sustainable" or comprehensively balanced development. At the Planet Earth Summit in 1992, the final documents on sustainable development were adopted. First of all, they described the problems of preservation the environment and the peculiarities of the development of social communities regarding threats to their existence in the future. In this sense, "sustainable development" was part of being, an integral part of the development of societies. However, the development of world communities in the XX century was more in line with the concept of "sustainable development" than it was in the first quarter of the 21 st century. The information society has deformed the optimized pertinence between the need to have and to be [2, p. 143]. The implementation of the Sustainable Development Strategy for almost thirty years has shown that the possible prognostic implications of the deep transformations of post-industrial society have not been taken into account in the principles of sustainable development. The formation of the informational format of societies changed the list of problems in the system of man - nature man which previously resolved through the evolutionary path of development. Previously, they were local rather than global.

In our view, during the past thirty years, there has been no global consensus on the implementation of a sustainable development strategy. First of all, a number of societies have adopted the principles of sustainable development in their regional contexts without a comprehensive economic basis. International Top Level Forums 2018-2020 demonstrated intent to collaborate. Sustainable development has proven effective only in the steady growth of new and increasingly threatening challenges that are beginning to bother humanity, not in arithmetic but geometric progression.

Key words: information space, sustainable development, structure, principles of sustainable development, system, analysis, synthesis, rationality, optimization, process, interpretation, principles. 